ISSN 2338-4778 (Print)

\title{
The Effectiveness of Retelling Short Story towards Students' Accuracy in Speaking Skill
}

\author{
Nur Hasanah Safei ${ }^{1}$, Dewi Atikah ${ }^{2}$ \\ nurhasanahsafei92@gmail.com \\ 1English Education Department of Tarbiyah dan Teacher Training Faculty \\ Institut Agama Islam Negeri Kendari, Indonesia
}

Received: 11 May 2020 Accepted: 28 May 2020

DOI: 10.24256/ideas.v8i1.1275

\begin{abstract}
The objective of this research is to find out the effectiveness of retelling short story toward students' accuracy in speaking skill. This research employed pre-experimental method which entails pre-test, treatment, and post-test. Speaking test was used in collecting the data. A total of 39 students of MTsN Makassar as the subject of this research.. The data on the students' speaking skill were analyzed using descriptive and inferential statistics. The results demonstrated that there was a differentiation between the students'accuracy in speaking skill before and after being thought through retelling short story. The null hypotesis (H0) was rejected and the alternative hypothesis (HI) was accepted because the t-test value was 5,42 which was higher than t-table value 2,024.. The mean score of the students before teaching retelling short story was 2,95 classified as poor score. After teaching retelling short story the mean score was 3,38 classified as a good score. Based on result of data analysis above, the researcher drew conclusion that retelling short story could effective toward students' accuracy in speaking skill.
\end{abstract}

Keywords: Accuracy, Effectiveness, Retelling Short Stories, Speaking Skill

\section{Introduction}

Speaking is the skill by human being to produce their idea and though into spoken-form. It is the skill by which (listeners) are most frequently judged and through which they make and lose friends. It is also the medium through which much language is learnt (Mitcalf, 2003; Masruddin, 2018). Learn to speak is obviously harder than understand spoken language. It is clearly illustrated in the fact of the graduates of junior high school and the senior high school. The problem come as students want to communicate in English but they could not perform the task successfully due to such possible reasons as tension, shyness or lack of effective communication skill in English. Students rarely speak English in their 
daily lives. Even though, they have learnt English for a couple of years, their ability and skill in speaking English is still poor, including the students of MTsN Model Makassar. Viewing on the phenomenon, the ability of the students to speak must be developed. The teacher must apply a proper technique to enlarge the knowledge and motivation of students. They realize that the best strategies for formatting the students to communicate actively in English is to change the situation in class through creates an interesting and motivating environment, the students are expected to be immersed in the activities given by the teachers. Thus, the English teachers are expected to think and make some efforts to increase their students' skill in speaking. They are hoped to make good preparation and planning and choose the best medium so that the students are active to talk.

Reading some previous studies, there are many communication activities that can develop the students' speaking skill. According to the researcher, one activity that can be expected is retelling stories. retelling story is refers to a technique of teaching english by presenting materials or stories using gestures, intonations, demonstrations, actions, facial expression and perhaps visual media to help students understand the lesson. (Ayu Chandra, 2008). Retelling short story is one of the oral production activities, it gives challenge to the students to build up the story from what they hear or read. (Dewijana Ali, 2000). Hernia (2003) found that the result of analysis on the tests shows that the students' ability to retell short stories is "good." It means that using short stories to improve students' ability in speaking skill is useful. While Rosniawar (2006) found that the use pair activities can develop students' speaking skill. Ratna Wulandari (2011) found that the result of the research shows that storytelling can be effective on students' speaking ability in order to become appropriate technique in improving students' speaking ability.

In retelling short stories, students are expected to speak English. By giving ideas, students can apply their linguistics knowledge of the language. Retelling provides opportunity for students to speak English more intelligibly. Students learn to speak in informal occasion while promoting their English mastery. Telling stories is a human habit. It is suitable for all ages, children, and adults until old people, like to listen or tell stories. Our parents or grandparents, when we were a child, liked to tell us stories. Though retelling relies heavily on memorization, it can be used as initial step to practice speaking, since the students are expected to use their own words to retell the story in various ways. Thus, this research tried to find the effectiveness of retelling short story toward students' accuracy in speaking skill.

\section{Method}

This research employed pre-experimental method which entails pre-test, treatment, and post-test. Through cluster random sampling there were 39 students of MTsN Negeri Makassar. The data was collected by using speaking test. 
The test consists of pre-test and post-test.

\section{Procedures of the Research}

Pretest

Before giving the treatment, pretes was administered to the students. In this part, themselves and told their purpose to the student. Then, the student were asked to retold the story given by researcher. It was intended to know the prior knowledge of the students. Later the researcher scored the students speaking skill based on their accuracy.

Treatment

During the treatment, the students were given a certain story. They retold stories after they read or listen it for a certain time. The treatment was conducted for four times and the class teaches twice a week.

The treatment conducted with the following procedure:

a. The researcher distributed the stories.

b. The researcher asked students to read the stories silently for 15 minutes.

c. The researcher read the story loudly to the class for three times with much animation.

d. The researcher asked the students what story is about and their difficulties.

e. The researcher explained the grammar used in stories.

f. The researcher explained the generic text.

g. The researcher sometimes was a model of the students.

h. This activity was held for the first, second, third and fourth meetings.

Post-test

The posttest was done after the treatment. The students were free to choose the stories would be retold.

The posttest was held with the following procedures:

a. The researcher explained about the test to the students.

b. The researcher asked the students to choose one story has gotten during the treatment.

c. The researcher tested the students' speaking ability through retelling short stories in term of accuracy.

\section{Score classification}

The students' accuracy was analyzed using the following criteria level introduced by Heaton (1988:100). Accuracy has something to do with the speeches that produced by the students, wheather it can be understood or not. Here are selected out the detailed of the explanation above with criteria. The term of accuracy is a kind of giving point of the student speaking skill in the term of its accent, pronounciation, and any lexical grammars errors. 
Table 1. Accuracy

\begin{tabular}{|c|c|c|}
\hline Classification & Score & Criteria \\
\hline Excellent & 6 & $\begin{array}{l}\text { Pronunciation is only very slightly } \\
\text { influenced by the mother tongue. } \\
\text { Two or three minor grammatical and } \\
\text { lexical errors. }\end{array}$ \\
\hline Very Good & 5 & $\begin{array}{l}\text { Pronunciation is slightly influenced } \\
\text { by the mother tongue but no serious } \\
\text { phonological errors. A few } \\
\text { grammatical and lexical errors but } \\
\text { most utterance are correct. }\end{array}$ \\
\hline Good & 4 & $\begin{array}{l}\text { Pronunciation is still moderately } \\
\text { influenced by the mother tongue but } \\
\text { no serious phonological errors. A } \\
\text { few grammatical and lexical errors } \\
\text { but only one or two major errors } \\
\text { causing confusing. }\end{array}$ \\
\hline Average & 3 & $\begin{array}{l}\text { Pronunciation is influenced ny the } \\
\text { mother tongue but only a few } \\
\text { serious phonological errors. Several } \\
\text { grammatical and lexical errors, some } \\
\text { of which cause confusion }\end{array}$ \\
\hline Poor & 2 & $\begin{array}{l}\text { Pronunciation seriously influenced } \\
\text { by mother tongue with errors } \\
\text { causing a breakdown in } \\
\text { communication. Many basic } \\
\text { grammatical and lexical errors. }\end{array}$ \\
\hline Very poor & 1 & $\begin{array}{l}\text { Serious pronounciation errors as } \\
\text { well as many basic grammatical and } \\
\text { lexical errors. No evidence of having } \\
\text { mastered any language skill and } \\
\text { areas practiced in the course. }\end{array}$ \\
\hline
\end{tabular}

Heaton (1988:100)

The research based on above scoring system used rate scales below:

Table 2. Rate scales

\begin{tabular}{|l|l|}
\hline Rating & Ability to communicate orally \\
\hline $5.01-6.00$ & Excellent \\
\hline $4.01-5.00$ & Very good \\
\hline $3.01-4.00$ & Good \\
\hline $2.01-3.00$ & Average \\
\hline
\end{tabular}




\begin{tabular}{|l|l|}
\hline $1.01-2.00$ & Poor \\
\hline $0.00-1.00$ & Very poor \\
\hline
\end{tabular}

\section{Results}

If the score variable was grouped according to Krasen classification, the distributtion of score frequency shown in the following table.

Table 3. The Distribution of Frequency and Percentage Score of Students' Pre-test and Post-test for Speaking Skill According to Accuracy.

\begin{tabular}{|l|l|l|l|l|l|l|}
\hline \multirow{2}{*}{ No } & Classification & Score & \multicolumn{2}{|c|}{ Pre-test } & \multicolumn{2}{c|}{ Post-test } \\
\cline { 4 - 7 } & & & Frequency & $\begin{array}{l}\text { Percentage } \\
(\%)\end{array}$ & Frequency & $\begin{array}{l}\text { Percentage } \\
\text { (\%) }\end{array}$ \\
\hline 1 & Excellent & 6 & - & 0 & - & 0 \\
\hline 2 & Very good & 5 & 1 & 2,56 & 4 & 10,25 \\
\hline 3 & Good & 4 & 6 & 15,38 & 14 & 35,89 \\
\hline 4 & Average & 3 & 22 & 56,41 & 14 & 35,89 \\
\hline 5 & Poor & 2 & 10 & 25,64 & 7 & 17,94 \\
\hline 6 & Very poor & 1 & - & 0 & - & 0 \\
\hline & Total & & $\mathbf{3 9}$ & $\mathbf{1 0 0}$ & $\mathbf{3 9}$ & $\mathbf{1 0 0}$ \\
\hline
\end{tabular}

The table 3, on pre-test shows that $10(25,64 \%)$ out of students were classified into poor score, $22(56,41 \%)$ out of them classified into average, $6(15,38 \%)$ classified into good score, 1 (2,56\%) out of them classified very good score and none of them classified into excellent score. From that result, it is included that students's speaking skill according to accuracy in pre-test was low.

On the other hand, the table above also shows the result of the students' speaking skill according to accuracy in post-test. There were $7(19,74 \%)$ out of the students categorized as poor, $14(35,89 \%)$ out of them categorized as average, 14 $(35,89 \%)$ categorized as good, and $4(10,25 \%)$ categorized into very good. It is concluded that the students' speaking skill according to accuracy in post-test was categorized as good. It is indicated that retelling short story was effective toward tstudents' speaking skill based on accuracy.

The descriptive analysis above was supported with the inferensial analysis by using t-test. T-test was used to evaluate the research hypotesis. It showed that there were significance different between the result of students' accuracy in speaking skill which marked as follow: 
Table 4. The Mean Score and Standard Deviation of the Students' Pre-test and Post-test

\begin{tabular}{|l|l|l|}
\hline & Mean Score & Standard Deviation \\
\hline Pre-test & 2,95 & 0,72 \\
\hline Post-test & 3,38 & 0,91 \\
\hline
\end{tabular}

Table 4 shows that there was the significance the mean score in pre-test and the post-test based on speaking test. In pre-test, the mean score was $(2,95)$ with the standard deviation $(0,72)$. In contrary for the post-test, the mean score was $(3,38)$ with the standard deviation $(0,91)$. So, it can concluded that retelling short story is effective toward the students' accuracy in speaking skill based on the speaking test.

In order to know whether the pre-test and post-test were significantly different, the researcher used t-test. The result of t-test can be shown of the following table.

Table 5. Distribution the Value of t-Test and t-Table in Pre-test and Post-test

\begin{tabular}{|l|l|l|}
\hline Variable & t-test & t-table \\
\hline & 5,42 & 2.024 \\
\hline
\end{tabular}

Based on the table 5 , the level signicances for speaking test, t-test was $(5,42)$ is grater than t-table (2.024). If the t-test is higher than t-table, it means that the hypotesis (H1) was accepted. So there was the significant different between the result of pre-test and the post-test by using retelling short story.

\section{Discussion}

The descriptive statistic analyses in the findings shows that the speaking quality of students, the mean score of the students in table 4 in pre-test is 2,95 and post-test is 3,38 . It means that there is a significant different between the mean score of the students' pre-test and the students' post-test. The result of the t-test indicates that the value 5,42 from the $t$-test is higher than the t-table 2.024 .

Based on the result of the data, it can be inferred that after treatment by using retelling short story, the students speaking skill has better than before. The use of retelling stories in teaching materials of MTsN Model Makassar can effective toward student's accuracy in speaking skill. This is line with Miller and Pennycuff (2008), retelling story in the classroom is one way to improve oral language. Pellowski states that retelling the story is one of the arts or crafts of narration of stories in verse/and prose. He also states that retelling story is an effective instructional strategy for enhancing the comprehension of proficient and less 
proficient students (Pellowski, in Eliwarti, 2013). It means that, retelling story is a component of authentic assessment that can be introduced when the students demonstrate proficiency in identifying key story element. Hence, retelling story can play an important based assessment of speaking role performance. More specifically, retelling story also helps students express ideas in the format of beginning, development, and ending, including the characters and setting a story has to have. Students also can tell riddles or jokes. For instances, at the very beginning of each class session, the teacher may call a few students to tell short riddles or jokes as an opening. In this way, not only will the teacher address students' speaking ability in term of accuracy, but also get the attention of the class (Kayi, 2006).

\section{Conclusion}

the researcher drew conclusion that retelling short story could effective to improve students' accuracy in speaking skill. The results demonstrated that there was a differentiation between the students'accuracy in speaking skill before and after being thought through retelling short story. The null hypotesis (H0) was rejected and the alternative hypothesis (HI) was accepted because the t-test value was 5,42 which was higher than t-table value 2,024.. The mean score of the students before teaching retelling short story was 2,95 classified as poor score. After teaching retelling short story the mean score was 3,38 classified as a good score.

\section{References}

Ali, Dewijana. (2000). Activating the Second Semester Students of English Department of Universitas Negeri Makassar in Speaking English Through retelling story. Thesis of UNM Makassar

Arikunto, Suharsimi. (1997). ProsedurPenelitian: SuatuPendekatan. Edisi V; Jakarta: RinekaCipta.

Eliwarti, Desrita. (2013) The Effectiveness of Group Retelling to Develop The Speaking Ability of The Second Year Student of SMP Babusallam Pekanbaru. Unpublished. Retrieved on April 20, 2013 from Academic journal-pdf.

Gay, L.R. (1998). Research: Competence for Analysist And Application. USA

Harmer, J. (1991) The Practical of English Language Teaching. London: Longman Group.

Heaton. J.B. (1988). Writing English Language Test. New York: Longman Group Uk Company

Hernia. (2003). The Ability of The Second Semester Students of Eglish Department of UMPAR to Retell Short Stories. Pare-pare: Thesis FKIP UMPAR. http:// www. Developinngteacher.com/ articles-techtraining/Speaking-emma2.htm.

Hornby, A S. (1995). Oxford Edvanced Learner's Dictionary. Oxford: Oxford University Press.

Kayi, Hayrie. (2006). Teaching Speaking: Activities to Promote Speaking in a 
Second Language. [online]. Retrieved on June 4, 2013 http://iteslj.org/Articles/KayiTeaching-Speaking.html

Kennedi, J. X. (1983). An Introduction to Fiction. Boston: Toronto. Little Brown and Company.

Masruddin, M. (2018). The Efficacy of Using Short Video through Group Work in Teaching Speaking to Indonesian English as Foreign Language (EFL) Students.

Arab World English Journal, 9 (3), 282-293. DOI:

https://dx.doi.org/10.24093/awej/vol9no3.19

Masruddin, M. (2018). The Students Interest towards the Use of Natural Approach in Teaching Speaking. IDEAS: Journal on English Language Teaching and Learning, Linguistics and Literature, 1(2). doi:https://doi.org/10.24256/ideas.v1i2.169

Mitcalf, Emma. (2003). The Implication of Teaching Conversation in The Classroom with Specific Reference to Advanced Learners And Genre.

Miller, Sara \& LisaPennycuff. (2008). The Power of Story: Using Storytelling to improve Literacy Learning. Journal of Cross-Disciplinary Perspectives in Education Vol. 1, No. 1(May 2008) 36-43.

Ratna, Wulandari. (2011). Improving Student Speaking Ability By Using Story Telling at The Second Year of SMP Negeri 2 Grogol. Thesis Unismuh Surakarta

Rosniawar. (2006). Using Pair Activities to Develop Students Speaking Skills. Makassar. Thesis FBS UNM 